\title{
ANALISIS SPEAKING SISWA KAMPUNG BAHASA BLOOM BANK MELALUI TREATMENT PERMAINAN 2 DIMENSI
}

\author{
Iwan Budiarso \\ Program Studi Teknik Informatika, Universitas Indraprasta PGRI \\ Email: budiarso.iwan@gmail.com
}

\begin{abstract}
Abstrak
Penelitian ini berupa analisis kemampuan speaking siswa melalui teknik treatment permainan 2 dimensi. Objek penelitiannya sebanyak 30 siswa di lembaga pendidikan Kampung Bahasa Bloom Bank Indonesia, Ciracas Jakarta Timur. Lembaga pendidikan ini merupakan lembaga non-profit dengan siswa dari kalangan keluarga tidak mampu. Tujuan penelitian ini adalah untuk memberikan teknik pengajaran bagi para pengajar, tutor, guru dalam proses belajar mengajar bahasa Inggris di lingkungan Kampung Bahasa Bloom Bank berupa treatment permainan 2 dimensi. Metode yang digunakan dalam penelitian ini adalah menggunakan metode deskriptif dengan pendekatan kualitatif yaitu dengan melihat hasil nilai speaking siswa setelah diberikan treatment permainan 2 dimensi. Nilai tersebut dianalisa untuk diambil kesimpulan. Dari hasil analisis menunjukkan bahwa nilai speaking yang diperoleh siswa bagus. Hal ini berarti, teknik treatment permainan 2 dimensi berhasil diaplikasikan di lingkungan Kampung Bahasa Bloom Bank untuk meningkatkan kemampuan speaking siswa.
\end{abstract}

Kata Kunci: speaking, treatment, permainan 2 dimensi

\begin{abstract}
This research is an analysis of students' speaking skill by using a $2 D$ game treatment technique. The object of this research is 30 students from an educational institution Kampung Bahasa Bloom Bank Indonesia located in Ciracas, East Jakarta. This educational institution is a non-profit organization conducting English teaching for students from poor families. The purpose of this research is to introduce a teaching technique in the form of treatment of $2 D$ game to instructors, tutors and teachers during English learning and teaching process in Kampung Bahasa Bloom Bank. The method employed in this research is a descriptive method with qualitative approach by drawing a conclusion from the analysis of the English speaking skill scores of students having received the treatment of $2 D$ game. From the analysis result, it can be concluded that the students' speaking skill scores are good. It means that this treatment has been successfully applied in Kampung Bahasa Bloom Bank environment to improve the speaking skill of the students.
\end{abstract}

Keywords: speaking, treatment, $2 D$ game

\section{Pendahuluan}

Di zaman era globalisasi, bahasa Inggris sangat diperlukan. Oleh karena itu, kemampuan bahasa Inggris sudah menjadi sebuah keharusan. Bahasa Inggris merupakan suatu instrument atau alat yang sangat penting untuk berkomunikasi dengan orang lain saat ini. Bahasa Inggris dipakai hampir di seluruh aspek kehidupan, mulai dari pelaku atau bidang pendidikan, ekonomi, pemerintahan, perkembangan teknologi dan bidang-bidang lainnya. Contoh sederhana yang ada di depan mata adalah dalam kehidupan pekerjaan, bahasa Inggris menjadi salah satu persyaratan wajib yang harus dimiliki atau dikuasi oleh calon pekerja atau pelamar kerja ketika ingin bergabung di sebuah perusahaan swasta nasional, badan usaha milik Negara dan atau instansi pemerintah. Dalam dunia pendidikan banyak buku-buku berbahasa Inggris yang menjadi rujukan oleh pembelajardan juga banyak sekali produkproduk dari luar negeri yang berbahasa Inggris terutama semenjak adanya pasar bebas MEA (Masyarakat Ekonomi Asean) sejak awal tahun 2015.Selain itu, perlu diketahui bahwa komunitas ekonomi ASEAN atau AEC (Asean Economy Community) telah menyepakati bahasa bisnis yang digunakan adalah bahasa Inggris. Ini menjadi catatan bagi seluruh warga 
Indonesia untuk berpikir keras bagaimana menyiapkan keterampilan berbahasa Inggris agar mampu menghadapi pasar bebas tersebut. Hal ini dapat dibayangkan, aktivitas dalam kehidupan setiap hari menggunakan bahasa Inggris, petunjuk atau aturan dalam peraturan dagang menggunakan bahasa Inggris. Pertanyaannya adalah apa yang terjadi jika tidak dapat berbahasa Inggris? Perlu direnungkan dan sekaligus disadari betapa pentingnya bahasa Inggris. Situasi seperti ini harapannyadijadikan sebagai pemicu untuk semangat belajar bahasa Inggris.

Menyadari akan pentingnya bahasa Inggris di masa sekarang dan yang akan datang, maka pembelajaran bahasa Inggris harus diberikan dan diterapkan sedini mungkin untuk semua kalangan warga Indonesia mulai dari tingkat taman kanak-kanak. Permasalahannya adalah bagaimana untuk kalangan keluarga yang tidak mampu dan tidak bisa mengenyam pendidikan formal.

Di Indonesia tidak sedikit lembaga-lembaga pendidikan yang menyediakan jasa pelatihan bahasa Inggris, namun bagi siswa yang ingin bergabung harus membayar uang masuk, uang pengembangan dan uang rutin selama pendidikan (SPP). Ini sudah dipastikan bahwa yang dapat menikmati lembaga-lembaga tersebut adalah hanya orang-orang mampu yang memiliki kondisi ekonomi berkecukupan. Kebanyakan dari mereka adalah dari pelajar sekolah-sekolah formal sebagai tambahan belajar di luar kelas (pendalaman materi) dan para profesional yang ingin memajukan karirnya melalui kemampuan berbahasa Inggris.

Berangkat dari permasalahan ini, banyak kalangan pemerhati pendidikan di Indonesia, khususnya di Ibu Kota Jakarta yang tergugah hatinya untuk membantu mereka yang tidak bisa mengenyam atau merasakan pendidikan selayaknya di sekolah-sekolah formal untuk mempelajari bahasa Inggris. Salah satu lembaga pendidikan bahasa Inggris di Jakarta timur bernama Kampung Bahasa Bloom Bank tepatnya berada di Jl. Jaya Makmur No. 99 Kelapa Dua Wetan Ciracas Cibubur.

Kampung Bahasa Bloom Bank Indonesia adalah sebagai lembaga non-profit yang peduli kalangan keluarga tidak mampu, mulai beroperasi sejak pertengahan tahun 2006 silam.Lembaga ini memfasilitasi mereka dalam belajar bahasa Inggris, baik dari segi sarana dan prasarana. Siswanya berasal dari berbagai latar belakang keluarga, seperti: yatim piatu, anak pemulung, anak putus sekolah, dan lain sebagainya. Bergabung menjadi siswa tidak ditentukan oleh batas usia. Mereka berusia antara 10 tahun sampai dengan 18 tahun. Jika dikategorikan sekolah formal pada umumnya mereka sedang menempuh pendidikan pada jenjang sekolah tingkat pertama sampai dengan sekolah lanjut tingkat atas.

Berdasarkan data yang diperoleh dari hasil observasi awal, Kampung Bahasa Bloom Bank memiliki guru bahasa Inggris yang tidak tetap, volunteers, siapa saja bisa menjadi guru bahasa Inggris. Di sisi lain, penulis juga mengamati pola pembalajaran bahasa Inggris tidak memiliki kurikulum yang dijadikan sebagai acuan pengajaran. Metode yang dipakai oleh pengajar menggunakan cara yang konvensional dengan pola hafalan dengan alat bantu mengajar yang kurang inovatif sehingga dalam proses pembelajarannya siswa tidak memiliki motivasi yang tinggi untuk mengikuti setiap kegiatan pembelajaran bahasa Inggris yang diberikan. Dengan kondisi seperti ini, maka harapan atau ekspektasi kompetensi siwa dalam belajar bahasa Inggris yang baik sulit terwujud.

Kendala lain yang penulis temui di Kampung Bahasa Bloom Bank adalah kesulitan siswa dalam mempraktekkan kemampuan speaking. Kemampuan ini sebagai salah satu aspek keterampilan berbahasa yang bersifat produktif, artinya suatu kemampuan yang dimiliki oleh seseorang untuk menyampaikan gagasan, pikiran, atau perasaan sehingga gagasan-gagasan yang ada dalam pikiran pembicara dapat dipahami orang lain. 
Melihat fenomena di atas, penulis ingin berkontribusi terhadap perkembangan dan kemajuan pembelajaran keterampilan bahasa Inggris di Kampung Bahasa tersebut dengan cara melakukan penelitian, menganalisa kemampuan speaking mereka melalui treatment permainan 2 Dimensi.

Penulis berharap, penelitian ini akanmemberikan manfaat bagi pengajar, tutor, atau guru di lingkungan Kampung Bahasa Bloom Bank dalam mengajar Bahasa Inggris, memberikan cara pandang yang berbeda bagaimana mengajar yang efektif dan menyenangkan.

\section{Tinjauan Pustaka}

\section{Keterampilan Berbicara (Speaking)}

Berbicara merupakan salah satu aspek dari empat keterampilan berbahasa. Dalam Kamus Besar Bahasa Indonesia berbicara adalah suatu kegiatan berkata, bercakap, berbahasa, melahirkan pendapat dengan perkataan atau tulisan dan sebagainya (Alwi, dkk, 2003: 148). Tarigan (2005a: 15) dalam bukunya menjelaskan definisi berbicara sebagai berikut:

"Berbicara adalah kemampuan mengucapkan bunyi-bunyi artikulasi atau kata-kata utuk mengekspresikan, menyatakan serta menyampaikan pikiran, gagasan, dan perasaan. Berbicara merupakan suatu sistem tanda-tanda yang dapat didengar (audience) dan yang kelihatan (visible) yang memanfaatkan sejumlah otot dan jaringan otot tubuh manusia demi maksud dan tujuan gagasan-gagasan atau ide yang dikombinasikan".

Dia menambahkan penjabaran tentang berbicara atau disebut sebagai komunikasi lisan yaitu suatu kegiatan yang mengikut sertakan sebagian besar anggota tubuh manusia untuk menyampaikan pesan kepada pendengar.

"Berbicara merupakan suatu kegiatan yang mengikut sertakan sebagian besar anggota tubuh manusia. Berbicara atau disebut komunikasi lisan merupakan suatu kegiatan perseorangan guna menyampaikan pesan secara lisan kepada pendengar atau audience". (Tarigan, 2005b: 30)

Dalam berbicara yang perlu diperhatikan tidak hanya berarti berbicara dengan lancar, tetapi juga harus memperhatikan cara penyampaiannya yang dapat juga dilakukan dengan cara yang singkat, padat namun jelas informasi yang disampaikan dan memiliki cara yang mengesankan. Mengesankan dalam hal ini berarti dapat menarik perhatian pendengar misalnya diselingi dengan cara mengucapkannya atau gerakan yang kreatif.

Tujuan utama dari berbicara adalah untuk komunikasi agar dapat menyampaikan informasi secara efektif, sebaiknya pembicara betul-betul memahami isi pembicaraannya, di samping juga harus dapat mengevaluasi efek dari komunikasinya terhadap pendengar. Jadi, bukan hanya apa yang dibicarakan, tetapi juga bagaimana mengemukakannya. Pendapat yang sama dikemukakan oleh Santosa (2007: 35) bahwa kegiatan berbicara dilakukan berdasarkan tujuan, situasi, cara penyampaian, dan jumlah pendengar pada saat melakukan aktivitas berbicara. Kegiatan berbicara tersebut dijelaskan sebagai berikut:

1. Berbicara berdasarkan tujuannya

a. Berbicara memberitahukan, melaporkan, dan menginformasikan.

Kegiatan berbicara jenis ini dilakukan seseorang jika ingin menjelaskan sesuatu proses menguraikan, menafsirkan, memberikan, menyebarkan atau menanam pengetahuan dan menjelaskan kaitan hubungan atau relasi antar benda, atau peristiwa.

b. Berbicara menghibur.

Berbicara jenis ini memerlukan kemampuan menarik perhatian pendengar. Suasana pembicaraannya bersifat santai dan penuh canda. Humor yang segar baik dalam gerak gerik, cara berbicara dan menggunakan kata atau kalimat akan memikat pendengar. 
c. Berbicara membujuk, mengajak, meyakinkan pendengarnya.

Kegiatan berbicara seperti ini akan berhasil jika pembicara benar-benar mengetahui, minat, kebutuhan, dan cita-cita pendengarnya.

2. Berbicara berdasarkan situasi

a. Berbicara formal

b. Berbicara non-formal

3. Berbicara berdasarkan cara penyampaiannya
a. Berbicara mendadak
b. Berbicara berdasarkan catatan
c. Berbicara berdasarkan hafalan
d. Berbicara dalam kelompok besar

Berdasarkan pendapat yang ada, maka dapat disimpulkan bahwa berbicara adalah suatu proses kemunikasi antara seseorang dengan orang lain atau sekelompok orang untuk mengungkapkan suatu pikiran, perasaan ataupun gagasan dengan lisan guna memberikan suatu informasi.Dalam penelitian ini, objek yang akan dianalisa adalah kemampuan berbicara (speaking) siswa di Kampung Bahasa Bloom Bank Indonesia.

\section{Media Pembelajaran}

Media pembelajaran adalah alat bantu proses belajar, yaitu alat bantu guru dalam mengajar serta sarana pembawa pesan dari sumber belajar ke penerima pesan belajar (siswa). Sebagai penyaji dan penyalur pesan, media belajar dalam hal-hal tertentu bisa mewakili guru atau pengajar menyajikan informasi belajar kepada siswa. Media pembelajaran juga merupakan segala sesuatu yang dapat digunakan untuk menyalurkan pesan serta dapat merangsang pikiran, perasaan, perhatian, dan kemampuan atau keterampilan pembelajar sehingga dapat mendorong terjadinya proses belajar. Dengan demikian media pembelajaran menempati posisi yang penting sebagai salah satu komponen sistem pembelajaran dan dapat mempengaruhi terhadap efektivitas belajar.

Menurut Arsyad (2011: 4) menjelaskan bahwa media pembelajaran adalah perantara yang membawa pesan atau informasi bertujuan instruksional atau mengandung maksud-maksud pengajaran antara sumber dan penerima. Media pembelajaran adalah sarana penyampaian pesan pembelajaran kaitannya dengan model pembelajaran langsung yaitu dengan cara guru berperan sebagai penyampai informasi dan dalam hal ini guru seyogyanya menggunakan berbagai media yang sesuai.

Menurut Heinich dan Molenda (2005) terdapat enam jenis dasar dari media pembelajaran, yaitu:

1. Teks

Merupakan elemen dasar dalam menyampaikan suatu informasi yang mempunyai berbagai jenis dan bentuk tulisan yang berupaya memberi daya tarik dalam penyampaian informasi.

2. Media audio

Membantu menyampaikan maklumat dengan lebih berkesan dan membantu meningkatkan daya tarikan terhadap sesuatu persembahan. Jenis audio termasuk suara latar, musik, atau rekaman suara, dan lainnya.

3. Media visual

Media yang dapat memberikan rangsangan-rangsangan visual seperti: gambar, photo, sketsa, diagram, bagan, grafik, kartun, poster, papan buletin, dan lainnya.

4. Media proyeksi gerak

Termasuk di dalamnya adalah film gerak, film gelang, program TV, video kaset $(\mathrm{CD}$, VCD, atau DVD).

5. Benda-benda tiruan atau miniature 
Termasuk di dalamnya benda-benda tiga dimensi yang dapat disentuh dan diraba oleh siswa. Media ini dibuat untuk mengatasi keterbatasan baik objek maupun situasi sehingga proses pembelajaran tetap berjalan dengan baik.

6. Manusia

Termasuk di dalamnya guru, siswa, atau pakar/ahli di bidang/materi tertentu.

Dari keenam media yang telah dijabarkan di atas, penulis mengambil satu media pembelajaran sebagai bentuk treatment yaitu permainan 2 dimensi. Bentuk permainan yang dimaksud adalah gambar-gambar benda yang ditemui setiap hari.

\section{Metodologi Penelitian}

Metode yang digunakan dalam penelitian ini adalah metode deskriptif dengan pendekatan kualitatif yaitu hasil penelitian yang kemudian diolah dan dianalisis untuk diambil kesimpulannya sehingga menghasilkan kesimpulan yang akan memperjelas gambaran mengenai objek yang diteliti.

Menurut Sugiyono (2009: 21) mendefinisikan bahwa: "Metode deskriptif adalah metode yang digunakan untuk menggambarkan atau menganalisis suatu hasil penelitian tetapi tidak digunakan untuk membuat kesimpulan yang lebih luas".

Sedangkan penelitian deskriptif yang dikemukakan oleh Mudrajat (2003: 8) adalah sebagai berikut: "Penelitian deskriptif meliputi kegiatan pengumpulan data untuk menjawab pertanyaan mengenai status terakhir dari subjek penelitian. Tipe yang paling umum dari penelitian deskriptif meliputi penilaian terhadap individu, organisasi atau keadaan tertentu".

Dalam penelitian ini, penulis melakukan dua tahapan. Tahapan pertama memberikan treatment permainan 2 dimensi kepada siswa, selanjutnya tahapan kedua memberikan assessing speaking menggunakan teknik Picture-Cued Task, hal ini untuk menganalisa sejauh mana kemampuan berbicara berbahasa Inggris setelah mengikuti treatment permainan 2 dimensi. Teknik ini penulis ambil dari buku yang berjudul Language Assessment Principles and Classroom Paractices, ditulis oleh H. Dougles Brown (2004) dari Universitas San Francisco State University.

Teknik Picture-Cued Tasks memberikan rangsangan berbicara kepada siswa untuk memberikan penjelasan-penjelasan terhadap gambar-gambar sederhana yang diberikan.

"One of the more popular ways to elicit oral language performance at both intensive and extensive levels is a picture-cued stimulus that requires a description from the test-taker. Pictures may be very simple, designed to elicit a word or a phrase; some what more elaborate and "busy"; or composed of a series that tells a story or incident." (Brown, 2004a: 151)

Dalam pelaksanaannya, penulis melakukan langkah-langkah assessing speaking dengan langkah sebagai berikut:

1. Picture-cued elicitation of minimal pairs.

Gambar-gambar sederhana diberikan kepada siswa dan mereka menunjuk setiap gambar yang ada. Langkah pertama ini, penulis memberikan pertanyaan what's this? Pertanyaan ini akan memancing siswa untuk menjawab sesuai apa yang mereka ketahui tentang gambar tersebut.

2. Picture-cued elicitation of comparatives.

Menyediakan dua gambar atau dua objek gambar dan meminta siswa membandingkan perbedaan dua gambar tersebut. Dengan membandingkan perbedaannya, maka siswa dapat mendeskripsikan bagian-bagian, ciri-ciri, dan mungkin bentuk-bentuk dari kedua gambar yang ditanyakan. 
3. Picture-cued elicitation of future tense.

Penulis memberikan gambar yang memiliki makna akan melakukan sesuatu. Misalnya, gambar anggota keluarga yang akan pergi berlibur. Penulis meminta siswa menjawab pertanyaan-pertanyaan simple future. Contoh: where are they going on for their vacation? What will they do there? What will she do? What will they buy? etc. Memicu siswa untuk menjawab apa yang ada di benak mereka tentang apa yang akan dilakukan oleh keluarga tersebut. Dapat dilihat dari tahap ini, siswa mampu menceritakan apa saja yang mungkin akan dilakukan setiap anggota keluarga di dalam gambar.

4. Picture-cued elicitation of nouns, negatives responses, numbers, and location.

Penulis memberikan gambar sebuah aktivitas keluarga di dalam ruang tamu yang sedang melakukan arisan. Pertanyaan yang diberikan kepada siswa seperti: what's this? What are these? What's that? Is this a chair? Are these clocks? Is she sitting? How many chairs are there? How many women are there? Where is the TV? Where is this chair? Please describe this person.Merangsang siswa akan menyebutkan benda-benda apa saja yang ada di dalam gambar tersebut, dilihat dari warnanya, jumlahnya, dan lain sebagainya.

5. Picture-cued elicitation of responses and description.

Langkah ini penulis memberikan dua gambar lukisan dan meminta siswa merespon dan mendeskripsikan kedua gambar tersebut. Misalnya dengan pertanyaan: When was this one painted? Which painting is older? How much does it cost? Which painting is more expensive? Which painting would you buy? Persuade me to buy it and describe the kinds of paintings you like in general,(respon yang akan diberikan siswa menunjukkan kemampuan mereka dalam mendeskripsikan gambar)

6. Map-cued elicitation of giving directions.

Langkah terakhir yaitu penulis memberikan sebuah gambar peta dan meminta siswa menjawab pertanyaan tentang bagaimana menuju ke sebuah alamat tujuan. Misalnya dengan memberikan pertanyaan lima tempat yang berbeda, please give me directions to the bank. Please give me directions to Pejaten Mall. How do I get to the post office? Can you tell me where the bookstore is? Please tell me how to get the library. Hal ini memberikan rangsangan kepada siswa untuk menunjukan arah lokasi, tata letak, posisi, dan juga bagaimana caranya untuk menuju atau mendapatkannya.

Pengambilan nilai dari langkah-langkah di atas, penulis menilai dari 4 aspek, yaitu: vocabulary, comprehension, grammar, dan pronunciation. Range nilai yang diberikan 0 sampai dengan 2, sesuai yang dijelaskan dalam buku Language Assessment Principles and Classroom Paractices, ditulis oleh H. Dougles Brown bahwa nilai 0 menunjukkan tidak ada jawaban dari siswa yang diuji (diam), nilai 1 memiliki arti cukup, dan nilai 2 menunjukkan hasil yang baik.

"Scoring for intensive tasks; 0 is for silence, seriously incorrect target-1 is for comprehensible, partially correct target-2 is for comprehensible, acceptable target." (Brown, 2004b: 157)

\section{Hasil dan Pembahasan}

Dari total keseluruhan siswa di Kampung Bahasa Bloom Bank, hanya 30 orang yang mengikuti assessment speaking. Jumlah 30 siswa tersebut memiliki kisaran usia 10 tahun sampai dengan 18 tahun dengan latar belakang kondisi keluarga yang hampir sama. Langkah-langkah dalam proses penelitian ini ada dua tahapan yang dilakukan. Tahapan pertama adalah dengan memberikan treatment permainan 2 dimensi kepada siswa dengan memberikan berbagai macam gambar-gambar yang ditemui setiap hari. Selanjutnya, tahapan kedua memberikan assessing speaking menggunakan teknik Picture-Cued Task, teknik yang diambil dari buku yang berjudul Language Assessment Principles and Classroom Paractices, ditulis oleh $\mathrm{H}$. Dougles Brown, tujuannya untuk menganalisa sejauh mana kemampuan berbicara berbahasa Inggris setelah mengikuti treatment permainan 2 dimensi. 
Hal ini bermaksud untuk mengukur apakah ada pencapaian hasil atau pemerolehan nilai siswa yang signifikan dengan melakukan trearment permainan 2 dimensi terhadap kemampuan berbicara (speaking). Berikut adalah daftar nilai yang mereka dapatkan:

Tabel 1. Daftar Nilai

\begin{tabular}{|c|c|c|c|c|c|}
\hline No. & Nama & Vocabulary & Comprehension & Grammar & Pronunciation \\
\hline 1 & $\mathrm{AA}$ & 2 & 2 & 2 & 1 \\
\hline 2 & $\mathrm{AD}$ & 2 & 2 & 2 & 1 \\
\hline 3 & BA & 1 & 1 & 1 & 1 \\
\hline 4 & $\mathrm{BC}$ & 2 & 2 & 2 & 1 \\
\hline 5 & BEO & 2 & 2 & 2 & 1 \\
\hline 6 & $\mathrm{BF}$ & 1 & 1 & 1 & 1 \\
\hline 7 & BT & 0 & 0 & 0 & 0 \\
\hline 8 & BR & 2 & 2 & 2 & 1 \\
\hline 9 & BS & 2 & 2 & 2 & 1 \\
\hline 10 & $\mathrm{CB}$ & 1 & 1 & 1 & 1 \\
\hline 11 & $\mathrm{CT}$ & 2 & 2 & 2 & 1 \\
\hline 12 & $\mathrm{CV}$ & 2 & 2 & 2 & 1 \\
\hline 13 & CWO & 1 & 1 & 1 & 1 \\
\hline 14 & DD & 1 & 0 & 0 & 0 \\
\hline 15 & DF & 2 & 2 & 1 & 1 \\
\hline 16 & DH & 1 & 1 & 1 & 1 \\
\hline 17 & RK & 1 & 1 & 1 & 1 \\
\hline 18 & $\mathrm{RM}$ & 1 & 1 & 1 & 1 \\
\hline 19 & SS & 1 & 1 & 1 & 1 \\
\hline 20 & ST & 2 & 2 & 2 & 2 \\
\hline 21 & $\mathrm{TT}$ & 0 & 0 & 0 & 0 \\
\hline 22 & TU & 2 & 2 & 1 & 1 \\
\hline 23 & TV & 1 & 1 & 2 & 1 \\
\hline 24 & $\mathrm{TZ}$ & 2 & 2 & 2 & 1 \\
\hline 25 & VA & 2 & 2 & 2 & 1 \\
\hline 26 & VD & 1 & 1 & 1 & 1 \\
\hline 27 & YA & 1 & 1 & 1 & 1 \\
\hline 28 & $\mathrm{YG}$ & 2 & 2 & 2 & 2 \\
\hline 29 & $\mathrm{ZA}$ & 2 & 2 & 2 & 1 \\
\hline 30 & $\mathrm{ZC}$ & 2 & 2 & 2 & 1 \\
\hline
\end{tabular}

Tabel di atas menunjukkan kemampuan berbicara bahasa Inggris siswa setelah dilakukan treatment permainan 2 dimensi sehingga dapat dilakukan analisis sebagai berikut:

1. Vocabulary (kosakata) menjadi poin pertama yang dinilai karena ini menunjukkan keseriusan siswa dalam belajar bahasa Inggris, sejauh mana penguasaan perbendaharaan kosakata yang mereka miliki. Kosakata menjadi hal yang penting dalam belajar bahasa Inggris karena digunakan sebagai mesin dari bahasa tersebut untuk mengekspresikan suatu pikiran, memahami bacaan, menulis dan mengungkapkan semua ide dalam bentuk tulisan atau pengucapan. Kosakata yang diujikan dalam tahapan kedua sudah pernah 
disampaikan pada saat melakukan treatment. Ketika mereka berkonsentrasi secara maksimal, maka mereka akan mengulang-ulang kosakata yang pernah dipelajari sebelumnya dan sudah dipastikan mereka akan dapat menjawab dengan baik saat diuji. Selain itu, assessment ini untuk mengetahui dan mengukur sejauh mana siswa mengenali dan memahami kelompok kelas dan jenis-jenis kata, seperti: kata benda (kata benda tunggal atau jamak), kata kerja (kata kerja transitif atau intransitif serta perubahan kata kerja ketika dipengaruhi oleh waktu/tensis), ciri-ciri kata sifat, dan ciri-ciri kata keterangan. Tujuan lain adalah untuk mengetahui pemahaman siswa dalam hal sederhana namun sering dilupakan oleh siswa yaitu penggunaan kata kerja bantuto be (is, am, are, was, were, been) dan kata kerja bantu dalam kalimat negatif dan introgatif, seperti; $d o$, does, did. Tabel 1 di atas menunjukkan bahwa siswa yang mendapat nilai2 (nilai baik) dalam menguasai vocabulary sebanyak 16 orang dengan siswa yang bernomor urut 1,2 , $4,5,8,9,11,12,15,20,22,24,25,28,29$, dan 30. Nilai1 (nilai cukup) diraih 12 orang, siswa yang bernomor urut $3,6,10,13,14,16,17,18,19,23,26$, dan 27. Selanjutnya nilai 0 (nilai buruk) ada 2 orang, siswa yang bernomor urut 7 dan 21 . Hal ini menunjukkan jumlah siswa yang menguasai vocabulary mendominasi nilai-nilai yang ada.

2. Kolom berikutnya adalah kemampuan comprehension (memahami kalimat). Ini menunjukkan kemampuan siswa dalam menangkap petanyaan-pertanyaan serta dapat memberikan jawaban dengan baik. Masing-masing siswa diberikan pertanyaanpertanyaan yang berkenaan dengan gambar-gambar yang ditunjukan, seperti; what's this? Where are they going on for their vacation? What will they do there? What will she do? What will they buy? Is this a chair? Are these clocks? Is she sitting? How many chairs are there? How many women are there? Where is the TV? Where is this chair? When was this one painted? Which painting is older? How much does it cost? Which painting is more expensive? Which painting would you buy? Persuade me to buy it and describe the kinds of paintings you like in general, please give me directions to the bank. Please give me directions to Pejaten Mall. How do I get to the post office? Can you tell me where the bookstore is? Please tell me how to get the library. Dari langkah ini dapat diketahui keberhasilan siswa ketika siswa dapat memjawab pertanyaan-pertanyaan di atas dengan tepat tanpa mengalami kebingungan memahami maksud dari tiap-tiap pertanyaan. Dari Tabel 1 di atas menunjukkan bahwa siswa yang mendapat nilai 2 (nilai baik) sebanyak 16 orang bernomor urut 1, 2, 4, 5, 8, 9, 11, 12, 15, 20, 22, 24, 25, 28, 29, dan 30. Adapun siswa yang mendapat nilai 1 (nilai cukup) sebanyak 11 orang, bernomor urut $3,6,10,13$, $16,17,18,19,23,26$, dan 27. Kemudian, siswa yang mendapat nilai0 (nilai buruk) sebanyak 3 orang, bernomor urut 7, 14, dan 21. Nilai tersebut menunjukkan jumlah siswa yang menguasai comprehension mendominasi nilai-nilai yang ada.

3. Aspek penilaian selanjutnya adalah grammar (tata bahasa). Penilaian ini untuk mengukur sejauh mana siswa dapat menyusun kalimat sesuai dengan tata bahasa atau kaidah bahasa Inggris yang benar ketika diberikan pertanyaan. Sebagai pembelajar bahasa Inggris, grammar merupakan hal dasar yang wajib dikuasi karena berkaitan dengan pembentukan struktur kalimat yang baik. Pembelajar bahasa Inggris dikatakan berhasil jika meraka dapat meletakkan subjek, predikat, dan objek dengan tepat. Mereka mampu memilih dan menggunakan kata kerja ketika dipengaruhi oleh keterangan waktu. Mereka paham kapan kata kerja mendapat tambahan ' $-s$ ' atau '-es' serta mereka mampu menentukan penggunaan kata kerja bentuk lampau past tenses dan bentuk past participle. Tabel $1 \mathrm{di}$ atas menunjukkan bahwa siswa yang mendapat nilai 2 (nilai baik) sebanyak 15 orang dengan nomor urut $1,2,4,5,8,9,11,12,20,23,24,25,28,29$, dan 30. Siswa yang mendapatkan nilai 1 (nilai cukup) sebanyak 12 orang dengan nomor urut daftar siwa 3, 6, $10,13,15,16,17,18,19,22,26$, dan 27. Adapun siswa yang mendapat nilai 0 (nilai buruk) sebanyak 3 orang dengan nomor urut daftar siswa 7, 14, dan 21. 
4. Penilaian terakhir adalah pronunciation (pelafalan). Pada bagian ini adalah untuk mengetahui sejauh mana pelafalan siswa terhadap suatu kata, hanya 2 orang yang mendapatkan nilai 2 yaitu siswa bernomor urut 20 dan 28, artinya dia dapat melafalkan dengan baik sesuai dengan penutur utama atau asli (native speaker). Nilai 1 (nilai cukup) diraih oleh 25 orang, dan nilai 0 (nilai buruk) diraih oleh 3 orang.

Penjabaran nilai-nilai di atas menunjukkan bahwa hasil penguasaan vocabulary, grammar, dan comprehension dapat dikategorikan berhasil, nilai 2 (nilai baik) mendominasi. Adapun nilai pronunciation diraih oleh 2 orang, artinya hanya dua orang yang dapat melafalkan dengan baik seperti penutur asli (native speaker).

Untuk lebih jelas pemerolehan nilai kemampuan berbicara Bahasa Inggris siswa Kampung Bahasa Bloom Bank Indonesia dapat dilihat pada Tabel di bawah ini:

Tabel 2. Rekapitulasi Nilai Berdasarkan Penilaian Brown \& Sahni

\begin{tabular}{clccc}
\hline No & Aspek Penilaian & $\begin{array}{c}\text { silence, seriously } \\
\text { incorrect } \\
\text { target }(\text { buruk) }\end{array}$ & $\begin{array}{c}\text { comprehensible, } \\
\text { partially correct } \\
\text { target (cukup) }\end{array}$ & $\begin{array}{c}\text { comprehensible, } \\
\text { acceptable } \\
\text { target (baik) }\end{array}$ \\
\hline 1 & Vocabulary & 2 siswa & 12 siswa & 16 siswa \\
2 & Comprehension & 3 siswa & 11 siswa & 16 siswa \\
3 & Grammar & 3 siswa & 12 siswa & 15 siswa \\
4 & Pronunciation & 3 siswa & 25 siswa & 2 siswa \\
\hline
\end{tabular}

Catatan: jumlah siswa yang mengikuti assessing speaking sebanyak 30 orang siswa.

\section{Simpulan dan Saran \\ Simpulan}

1. Dilihat dari hasil analisa terhadap nilai vocabulary siswa Kampung Bahasa Bloom Bank nilai baik sebanyak 16 siswa, nilai cukup sebanyak 12 siswa, maka nilai-nilai tersebut menunjukkan bahwa permainan 2 dimensi memberikan kontribusi yang baik terhadap penambahan perbendaharaan kosakata siswa. Meskipun ada 2 siswa yang mendapat nilai buruk.

2. Analisa terhadap nilai comprehension terdapat 16 siswa yang mendapatkan nilai baik, 11 siswa yang memperoleh nilai cukup, dan selebihnya ada 3 siswa yang mendapatkan nilai buruk, maka ini menunjukkan bahwa permainan 2 dimensi memberikan pengaruh yang baik terhadap pemahaman siswa dalam memahami sebuah kalimat.

3. Aspek penilaian untuk grammar menunjukkan nilai baik sebanyak 15 siswa, nilai cukup sebanyak 12 siswa, dan nilai buruk sebayak 3 siswa, maka dapat dikategorikan bahwa permainan 2 dimensi memberikan kontribusi yang baik terhadap pemahaman kaidahkaidah bahasa Inggris atau tata bahasa Inggris siswa.

4. Adapun aspek penilaian pronunciation didominasi oleh siswa yang mendapatkan nilai cukup yaitu sebanyak 25 siswa, sementara hanya ada 2 siswa yang mendapatkan nilai baik dan selebihnya mendapatkan nilai buruk sebanyak 3 siswa. Hal ini menunjukkan bahwauntuk pembelajar bahasa asing, nilai-nilai tersebut sangat wajar karena dipengaruhi oleh dialek lokal siswa dan perlu waktu serta latihan yang maksimal untuk dapat mengucapkan kata demi kata seperti penutur aslinya (native speaker).

\section{Saran}

Berdasarkan hasil penelitian dan pembahasan serta kesimpulan yang telah dikemukakan di atas, berikut ini adalah beberapa saran yang diharapkan dapat menjadi masukan dan bahan pertimbangan dalam pembelajaran bahasa Inggris, yaitu:

1. Treatment permainan 2 dimensi hendaknya dapat diaplikasikan oleh para pengajar, tutor, atau guru dalam proses belajar bahasa Inggris terutama untuk meningkatkan kemampuan speaking siswa, baik di sekolah formal maupun non-formal. 
2. Permainan 2 dimensi ini menggunakan gambar-gambar sebagai media belajar, maka diharapkan untuk para pengajar, tutor, atau guru dapat mengeksplorasi berbagai macam gambar yang ditemui setiap hari. Cara ini diharapkan akan dapat meningkatkan motivasi belajar siswa dalam mempelajari bahasa Inggris, situasi belajar menjadi menarik, menyenangkan, dan tidak membosankan.

\section{Daftar Pustaka}

Alwi, H., dkk. (2003). Kamus Besar Bahasa Indonesia. Jakarta: Balai Pustaka.

Arsyad, Azhar. (2011). Media Pembelajaran. Jakarta: Rajawali Pers.

Brown, H. D. (2004). Language Assesment: Principle and Classroom Practice. New York: Person Education.

Heinich dan Molenda. (2005). Instructional Media and Technology for Learning. Upper Saddle Rive. NJ: Pearson Education, Inc.

Mudrajat, Kuncoro. (2003). Metode Riset untuk Bisnis dan Ekonomi. Jakarta: Erlangga.

Santosa Puji, dkk. (2007). Materi dan Pembelajaran Bahasa Indonesia SD. Jakarta: Universitas Terbuka.

Sugiyono. (2009). Metode Penelitian Kuantitatif dan Kualitatif. Bandung: CV. Alfabeta

Tarigan, H. G. (2005). Pengajaran Pragmatik. Bandung: Angkasa. 